\title{
Application Of The 5S Method In an Algerian Firm
}

\author{
Rabia Azzemou*, Myriam Noure ddine
}

Computer Science Department, University of Science and Technology of Oran USTO 'Mohamed BOUDIAF', Oran, 31000, Algeria

\begin{abstract}
In an unstable context characterized by the turbulence of markets and the competitive pressures, the firm is forced to adopt a strategy of development to rema in competitive. The membership of Algeria to several global organizations imposes on the Algerian company a need for particular adaptation. New challenges await the Algerian firm, changes generated by the liberation of exchange and world competition. To improve its competitiveness to prepare for international competition, this article proposes an adaptation of the management system of the Algerian firm through a Lean Manufacturing tool, the 5S method. The 5S tool improves productivity because it is designed to check the manufacturing process and ensure that dysfunctions are identified and dealt. The validation of the $5 \mathrm{~S}$ method was tried on essential equipment in the gas Algerian company. Every "S" is applied to every dysfunction of this equip ment found from the Ishika wa diagram and the results are proposed solutions or actions that will allow an imp rovement of the production process by elimination of the wasting and therefore improve the competitiveness of this company.
\end{abstract}

Keywords Algerian Firm, Competitiveness, 5S Method, Ishikawa Diagram

\section{Introduction}

Today, to be competitive in an economy means obeying the rules of the world's commercial system and satisfying more and more demanding markets.

The competitive environment became a fundamental preoccupation in modern economy for developed and emerging countries. Indeed, the prosperity of a country depends on its competitiveness which depends on the productivity of firms. In spite of its recognized importance, the understanding of the concept of competitiveness may be ambiguous[1],[2],[3],[4]. The a mb iguity underlined by many authors is due to its change in front of variations of market conditions. To address this ambiguity, it is necessary to specify entities such as: state economy, sector, company, product and service. There are certainly systematic links between these various concepts. Indeed, we can speak about a competitive economy only through a competitive sector, a competitive firm and a competitive product[4]. So, non-competitive products lead to a non-competitive firm and can engender a non-competitive sector.

The Organization for Economic Co-operation and Development (OECD) defines competitiveness as being the latitude which a country has, evolving in conditions of a free and fair market, to produce the goods and the services which satisfy the international standards of the market, while maintaining and increasing simultaneously the real income

* Rabia Azzemou:

rabiazzemou@gmail.com (Rabia Azzemou)

Published online at http://journal.sapub.org/mm

Copyright (C) 2012 Scientific \& Academic Publishing. All Rights Reserved of its inhabitants in the long term. It is only possible with a productivity increase[5]. Th is is a macroeconomic defin ition, while competitiveness is initially a firm concept transposed to a macroeconomic scale [6].

The competitiveness of a firm is analyzed through the degree of flexibility of its structure[7]. For a firm to be competitive, its structure has to be in compliance with the requirements of its environment to assure its sustainability. In other words, if the environment changes the structure of the firm must adapt. So, companies of developing countries have to adopt effective and innovative commercial practices as well as supporting infrastructure dynamic business.

To avoid remaining in the margin, Algeria following the example of developing countries has to participate more actively in the current negotiations and strive to become more competitive in exports. In this context, an Algerian company upgrade plan has been set up since 1999 . However the upgrade of companies remains insufficient to allow them to face competition and to ensure sustainable growth. In spite of large sums invested in the various programs, the results are mitigated because companies did not show a turned out interest. To maintain and perpetuate activities, both in the domestic markets and in exports, the Algerian firm has to improve its competitiveness. The operating margin being restricted, it is essential that it has a quality organization, capable of mobilizing its resources and reaching its objectives. Numerous firms make a commitment, with or without outside help, and initiate improvement to pilot quality, logistics and human resources management, but the results are often disappointing because the system foundations are not strong. The firm is forced to set up a new form of organization adapted to the management and the 
strategy of the existing market. It is translated by the implementation of new concepts of management.

At present, Lean Manufacturing establishes a competitive method to analyze the dysfunctions of the firm and set up an action plan to improve its performance. It is an organizational shape adapted to a world environment, g lobal and quickly evolutionary. Indeed, in the current competitive, the company cannot increase the sale price but can decrease the production cost by eliminating the wasting. It consists on eliminating the activities which do not contribute to the valuable creation for the stakeholders (more specially the customers) so as to concentrate on critical process resources.

The objective of this paper is suggesting to companies to adopt Lean which will allow them to set up an environment of actions and improve their competitiveness. So, Lean Manufacturing comes upstream to the program of upgrade of the SMEs.

In this context, we present in the second section the particular specification of the Algerian company, the program of upgrade and its impact. The third section is dedicated to the Lean Manufacturing and its application with the adopted approach is exposed in the fourth section. The last section describes the approach validation on an industrial Algerian firm. The results are proposed solutions or actions that will allow an improvement of the production process and therefore its competitiveness.

\section{The Algerian Firm}

With globalization, Algerian firms are forced to evolve in a context of commercial opening and greater competition. It becomes, then, vital for them to seriously improve their internal competitiveness (on their internal market) but also external competitiveness (on the export market). Through signature of the GATT/WTO agreement, association agreement with Europe, as well as other regional and bilateral cooperation with partner countries, Algeria is involved in a double dynamics of globalization and regionalization.

This dynamic is synonymous to challenges, the first of which is undoubtedly the capacity of the Algerian economy to generate a competitive offer to overseas markets, and also, to meet the challenge of a domestic market competition increase, and this because of the customs dismantling of the tariff barriers. If some Algerian firms watch more or less passively this process, and implicitly accepting the programming of their disappearance, others on the contrary are not afraid of joining determinedly the competition. These Firms became aware that competitiveness is their only hope. The globalization requires adaptation and a radical transformation of firms' management systems, as well as their processes of production.

To reach the international level of competitiveness, all former management practices and methods must be changed. The economic reforms of the last ten years have driven a dynamics in favor of SMEs. But the current socioeconomic environment imposes radical changes in firms; so the Algerian government has displayed efforts to support and strengthen the competitiveness of the Algerian companies.

In this context, the Algerian authorities have implemented a system of upgrading national firms aiming at acting on the constraints inherent and external to the Algerian enterprise, to help it adapt to the new market conditions, to improve competitiveness, to enhance export capability and integrate activities, and to develop a capacity for consolidation and growth.

\subsection{The Upgrade}

The concept of company upgrading has emerged from the Portuguese experience in 1988. In Maghreb, Tunisia in 1996, then Morocco in 2002, have both put upgrade programs in place their companies following the agreement signed with the European Union foreseeing a dismantling of tariffs and a more open economy, which imp lied competition and rivalry. The upgrade is a set of material and non-material actions (ass ets of competitiveness) that are set up in order to upgrade the company performance and the competitiveness. It is a process which aims to assist the company to adapt itself to the requirements of economic opening, competition and free exchange. The aim thus consists of helping the company to keep its costs under control, to improve the quality of its products, to innovate and to perfect management systems. The success of these programs requires business climate improvement, institution efficiency, regulations de-bureaucr atization (administrative slowness, bureaucracy) and procedures simplification (difficulties in accessing bank credit). To better face the new world economic environ ment challenges as well as the technological and management upgrade of companies, the Algerian government implement ed support programs for s mall and medium-sized enterprises to promote competitiveness and face the competition.

\subsection{The Various Programs}

The first upgrade program with the objective of competitiveness improvement and industrial restructuring support in Algeria appeared in 1998 with the integrated program of the United Nations Organization for Industrial Develop ment (UNIDO). Created in close collaboration with the Ministry of Industry and Restructuring (MIR), the actions of the UNIDO integrated program has inspired another upgrade program, the SME, financed by the European Union[8].

Within the framework of the Mediterranean Euro partnership, the support program for the development of SMEs/SMIs is a program co financed by the European Commission and by the Ministry of SMEs and Crafts (MPMEA), The object ive of the EDPME upgrade program is to significantly improve the Algerian SME competitiveness by aligning itself to the international standards of organization and management.

The national upgrade program for Algerian SMEs completes and continues the already existing upgrade 
frameworks. The quoted upgrade programs concern SMEs with more than 20 employees. The Ministry of SMEs and Crafts initiated a program which would concern all SMEs as defined in the 2001 Orientation Act as well as their supporting structures. The access to the upgrade program financed by the State has just been widened to all private enterprises of all sizes. Up to now, only SMEs having more than 9 employees (20 in the BTPH) are eligible. This limitation has been lifted, henceforth; even very small firms (TPEs) are eligible now. The TPEs represent more than $90 \%$ of the national economic fabric (Min istry of Industry, SMEs and Promoting Investments).

The supporting program for SMEs/SMIs and for the control of information and communication technologies (PME II) aims at contributing to the modernization and to the development of the sector of Algerian small and medium-sized enterprises. The PME II concerns companies committed to modernization programs relevant to a certain number of target sectors, with the aim of disseminating good practices to the rest of the SMEs.

\subsection{Impact of the Upgrade on the Algerian Firm}

Has the implemented upgrading program to prepare the integration of Algerian firms into the international market allowed the involved firms to be more successful and more competitive? Thanks to a strong political commitment to ensure the promotion and the development of the SMEs, the upgrading program piloted by the National Agency of development of SMEs (ANDPME) has a 3.75 billion euro overall budget. This plan expects to upgrade 20000 firms and will last until 2014. The preliminary evaluation shows a certain progress (examp le a national canning co mpany which became a leader in the Algerian food industry), but gives a glimpse about important barriers at the internal and external level of the company (Table 1). Besides, the deficiencies are understandable due to Algerian inheritance of the economy stemming from its development model of the sixties and seventy centered on large public enterprises, and where private enterprises were marg inalized for a very long time and left at the mercy of the informal sector[9].

Table 1. Barriersto the upgrade

\begin{tabular}{|c|c|}
\hline At the internal level & At the external level \\
\hline Lack of interest from & Rigidity of the inst it utional \\
business managers, & environment, \\
Lack of strat egy, & Problems relative to the industrial \\
Lack of qualified human & real estate, \\
resources, & Heaviness and slowness of \\
Deficiencies in organization & administrative formalities, \\
and management. & Lack of information system, \\
& Informal economy \\
\hline
\end{tabular}

The important process that has been set up did not lead to the expected results, such as facing competition of foreign products on the internal market and conquering overseas markets. Despite commitment of the state, will this upgrading process allow our firms to face to foreign competition? Such as it is, it seems difficult to be realized because success does not depend solely on the quality of the global diagnosis (technology, organization and culture). From then on, it is important to take into account all these factors and find out a way to articulate the company around these conflicting constraints. To reach a renewal of dynamis $m$, we recommend to Algerian companies to adapt Lean Manufacturing which offers promising perspectives in competitiveness.

\section{Alternative: Lean Manufacturing}

In strong competition, firms cannot count only on the increase of work intensity to assure profitability. On the other hand, customers demand high quality products at low prices and the firm faces increased competition, by consequence it has to improve its productivity to remain on the market. This led firms to adopt Lean manufacturing which turns out to be an interesting way to improve long-term firms' performance[10]. Lean Manufacturing aims at optimizing all the processes of the firm, eliminating waste and implementing a light, agile and effective organization. Lean improves performance, that is, productivity and quality. In spite of large sums invested in the various programs, the results are mitigated because companies did not show a turned out interest. Besides, the success of this program is bound to the plan set up piloting and accompanying all changes. The coverage of the problems bound to the environment of the company is a major condition to give a chance to our companies to face the competition local, often unfair competition, and to face the very rough international competition. So, Lean Manufacturi ng comes upstream to the program of upgrade of the SMEs.

\subsection{Historical Background}

The Toyota Production System (TPS) was developed by Ohno in the 50s. It is considered as the best production model in the world[11] and is the precursor of the Lean Manufacturing. Initially implemented in the Japanese automotive sector, Lean Manufacturing has given birth to nowadays recognized techniques and adopted successfully by the biggest companies in many industrial do mains.

These techniques allow for a production time reduction, waste elimination, stocks minimization, quality improveme nt, capacity increase of existing installations, lower global costs and better value to customers.

Having demonstrated its effectiveness in the automobile environment, Lean inspired by TPS became a standard of organization and service for industrial companies. It is a production excellence system[11], an integrated system resting on the operational system, the management system and culture[12].

Lean translates into optimal flow management, better use of resources and respect for men and women. It translates also into a management system in which employees can 
completely develop their capacities by an active participation to the organization and to the work task improvement[13]. The Lean approach was first applied to world automotive sector and its subcontractors[14, 15].

The beginnings of Lean appeared in France within the two big companies: Renault and Citroën[11]. Other non automotive sectors have adopted the Lean approach such as the railroad sector (Alstom), cosmetics (L’Oréal), chemistry (Rhodia), floor coverings (Tarkett) and the metal industry (Alcan). Nowadays, the aerospace industry, electronics, the computer industry and all mass-market product industries have implemented Lean[16, 17]. Besides, Lean has extended to public services (administration, hospitals, and air transportation). Moreover, Lean’s principles apply to small and medium-sized enterprises[18, 19] as well as big companies [11].

\subsection{Basic Concepts}

The Lean approach integrates a set of principles, practices, tools and techniques conceived to eradicate the causes of bad operational performance. The objective of Lean is to optimize quality, costs, deadlines and productivity. To reach such an objective, it is necessary to act on the three ineffectiveness sources of any operational system: wasting, variability and lack of flexibility[12].

The elimination of wasting (Muda in Japanese) is at the core of the Lean approach. Wasting is defined as an action or a situation of non-value-creating for the customer[11]. Ohno identified seven types of wasting[20], among these, the overproduction is considered by Ohno as the most problematic, because it engenders and conceals all other types of wasting. So, the overproduction creates inevitably a surplus of stocks and this harms inevitably the continuous improvement[21]. An eighth type of wasting based on unexploited creativity has been added recently to the list by Liker[21]. Wasting covers all what adds costs and does not bring any value to the customer. ECOMANIA is mnemonic to remember the eight wasting types[18] group as shown in the table below (Table 2).

\subsection{Lean Manufacturing Analysis}

We distinguish four levels of the Lean system analysis[11].

Redefinition of the added value produced by a firm: on one hand, the added value of the goods must be defined from the customer the point of view. On the other hand, the firm has to assure a continuous flow of the value along its production line (Chasing stocks).

Plan of production: the firm produces "by pulling" its production according to the demand and not "pushing" according to local production capacities. The productive tasks are standardized so as to facilitate the continuous improvement by suppressing non creative value tasks. The firm maintains rich partnership relations with suppliers and incites them to adopt its ways of production.

Manager attitude: the managers and the workers have to find and eliminate underlying causes of problems as soon as they arise. Every employee is incited to reflect and to propose improvements of the productive system. These results in punctual construction sites of improvement (KAIZEN). Management has to take place "on the ground" because only direct experience of cris is situations allows for an effective diagnosis (GENCHI GENBUTSI). Managers have to see the reality of dysfunctions by going to factories and they follow different process of manufacturing.

Long-term strategy: the firm has to give priority to long term issues by clarifying its global objective and registering it in a sustainable way for the future. Also, the firm has to seek permanent excellence. Firm seeks always excellence too keep its place of leaders in the market by dealing competition and supplying product with high quality.

Table 2. Wastings or Muda (Adapted by Bedry)

\begin{tabular}{|c|c|c|}
\hline $\mathrm{E}$ & $\begin{array}{l}\text { Excess of production } \\
\text { or load }\end{array}$ & $\begin{array}{l}\text { Producing more than the required } \\
\text { cust omer demand }\end{array}$ \\
\hline C & $\begin{array}{l}\text { Useless Circulation } \\
\text { of machines and men }\end{array}$ & $\begin{array}{l}\text { Transporting without with no } \\
\text { real utility }\end{array}$ \\
\hline $\mathrm{O}$ & Useless Operations & $\begin{array}{l}\text { Any superfluous operation in the } \\
\text { process, realizing tasks which can } \\
\text { be eliminated }\end{array}$ \\
\hline M & $\begin{array}{c}\text { Useless or } \\
\text { unsuitable Movements }\end{array}$ & $\begin{array}{l}\text { Realizing useless movements } \\
\text { during work. It can damage the } \\
\text { health of the staff }\end{array}$ \\
\hline A & $\begin{array}{l}\text { Accumulation of stocks } \\
\text { And inventory }\end{array}$ & $\begin{array}{l}\text { Store quantities superior to the } \\
\text { necessary quant ity for the } \\
\text { following stage of the } \\
\text { manufacturing process. The stock } \\
\text { represents immobilized money }\end{array}$ \\
\hline $\mathrm{N}$ & Non-compliant & $\begin{array}{l}\text { Make defective products, that } \\
\text { must be rectified, or that do not } \\
\text { meet characteristics required by } \\
\text { the customers. }\end{array}$ \\
\hline I & $\begin{array}{l}\text { Inoccupation of } \\
\text { machines } \\
\text { And people }\end{array}$ & $\begin{array}{l}\text { Waste of time, awaiting } \\
\text { instructions, absence, lack of } \\
\text { implication }\end{array}$ \\
\hline A & A priori & $\begin{array}{l}\text { Main wasting at the origin of } \\
\text { others }\end{array}$ \\
\hline
\end{tabular}

\section{Adopted approach in Lean Manufacturing}

Any approach should begin by stating the pursued objectives to give meaning to further actions. The Lean approach starts downstream and goes back upstream using proper tools and common sense to reach intensification of the organization competitiveness. Lean does not suggest starting from zero, but leans on existing status and acts on the ground. It is based on human factor and teams must be sensitive to pursue any wasting wherever stands their intervention and their role in the organization. Their work must be directed and guided by the notion of added value.

Lean has to create value by eliminating wasting and identify it; the company will base on Lean concepts and will 
move forward step by step in the implementation of new procedures while modifying its habits for the long term.

\subsection{Tools for Lean Manufacturing}

Lean Manufacturing includes several tools which apply to all the environments and facilitate actions of transformation of the firm. A mong these tools we quote[11]:

5S: basic rules for order and discipline, they are inevitable preliminaries for any project of improvement,

Visual management: steering base for continuous improvement of everyday life which objective is to inform in real time and to allow immediate reaction to solving problems,

Kanban: production organization system with maps or via a simple visual system allowing to view flows and to reduce important inventory and stocks,

Poka Yoke: simple system allowing to avoid operators involuntary errors and is called " anti-error system ",

Single Minute Exchange Die (SMED): Deepening of value-added optimization time, it is an organization method for optimizing an unproductive functioning situation to gain in flexibility,

Value Stream Mapping (VSM): a method of analysis which allows defining the main productivity reserve of a production unit by tracing the complete room production flow. The flow of parts measured time, stock levels of and their value, allows defining a certain number of improvement construction sites to be set up first and foremost in a Lean Manufacturing approach.

Total Productive Maintenance (TPM): it is an essential Lean Manufacturing tool that measures breakdowns and machine stops as well as their associated risks. A corrective action plan can be set up then, as well as a real preventive maintenance management.

\subsection{Adopted Approach: The 5S method}

We opted for the 5S approach because it is a basic tool favoring an environment of effective work, creating a dynamics of change, reducing waste and moving the company into the change approach. This approach establishes economic stakes as well as permanent progress and its application allows building robust foundations of Lean manufacturing.

This approach is a part of fundamental practices that companies have to master, which in principle is easy to understand and its implementation does not require a particular know-how, not an important financial investment. The "5S" is an abbreviation of five Japanese words beginning with S: Seiri, Seiton, Seiso, Seiketsu, Shitsuke. They consist of a process and a method of creation and preservation of an organized, clean and successful workspace. The "5S" (Table 3 ) are essential in an effective elimination of wasting which is the ma in objective to change mentalities and to start a politics of continuous improvement[22, 23]. It is the first implemented tool in an approach Lean.
It is a professional approach and cannot be improvised. All the services of the company are concerned (from ordering to expedition of the product) and one should not consider that only workshops do and have to practice this approach. A firm is judged by clients through its holding, speed, reception presentation, sales network, head office; the first impression that it gives is organization of its workshops.

This approach applied with methodology and rigor exhibits visible and computable results on cleanliness, environment, in-house atmosphere, brand image of the firm, quality but also safety. It also establishes an approach of continuous improvement. It is an evolutionary cycle which follows the principle of the Deming wheel[24] called Plan Do - Check - Act (PDCA).

The first cleaning serving to establish the inventory of fixtures can be exploited as:

Plan": define the objectives to reach and to plan the implementation of actions,

"Do": it is about the implementation of corrective actions,

"Check": this phase consists in verify ing the infringement of the fixed objectives,

"Act": according to the results of the previous phase it is advisable to take precautionary measures.

Table 3. Method 5S

\begin{tabular}{|c|c|c|c|}
\hline Name & Definition & Activities & $\begin{array}{l}\text { Resulting } \\
\text { Profits }\end{array}$ \\
\hline 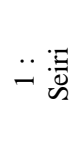 & 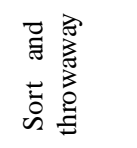 & $\begin{array}{l}\text { Consists on keeping only } \\
\text { what is necessary and } \\
\text { Eliminating the useless. }\end{array}$ & $\begin{array}{l}\text { Facilitates } \\
\text { the } \\
\text { identification } \\
\text { of the wasting }\end{array}$ \\
\hline$\ddot{\sim} \cdot \stackrel{\tilde{0}}{\tilde{\varpi}}$ & $\begin{array}{l}\Xi \\
\text { 总 } \\
\text { : }\end{array}$ & $\begin{array}{l}\text { Advocate the } \\
\text { generalization of the } \\
\text { doctrine "A place for } \\
\text { everything and } \\
\text { everything on its place" }\end{array}$ & $\begin{array}{c}\text { Allow a } \\
\text { visual control }\end{array}$ \\
\hline$\ddot{m}: \stackrel{\circ}{\mathscr{n}}$ & $\frac{\text { ฮี }}{0}$ & $\begin{array}{l}\text { A means to discover } \\
\text { anomalies and gaps. }\end{array}$ & $\begin{array}{c}\text { Make the } \\
\text { perfect quality } \\
\text { a reality }\end{array}$ \\
\hline.$\ddot{\frac{\sigma}{\ddot{g}}}$ & 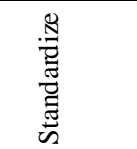 & $\begin{array}{l}\text { Perpet uate the } 3 \text { first } \\
\text { S's by means of } \\
\text { systems and procedures }\end{array}$ & $\begin{array}{c}\text { Allow } \\
\text { standardization } \\
\text { of operations }\end{array}$ \\
\hline 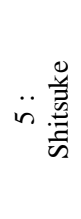 & 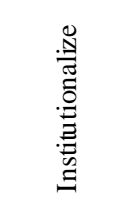 & $\begin{array}{l}\text { Maintain a stability of } \\
\text { the working } \\
\text { environment. }\end{array}$ & $\begin{array}{l}\text { Favor the } \\
\text { safety, } \\
\text { Contributeto } \\
\text { the satisfaction } \\
\text { of the } \\
\text { employees. }\end{array}$ \\
\hline
\end{tabular}

5S seems evident and full of common sense but sufficient attention is rarely played and few efforts to put them into practice are made. This method may seem superficial and simply linger to make a systematic fuss on working environment but the real reason of its implementation is to locate the problems at once. Its objective is the elimination of 
the wasting (in time, space, materials and efficiency). It thus has a direct impact on all the wasting and consequently on the improvement of quality, costs and deadlines. This approach allows advantages from which the employees are going to benefit. The first three stages (Seiri, Seiton, and Seiso) are concrete actions. They are the most difficult to set up because they require to review methods of work and require making a big change. The last two phases (Seiketsu, Shitsuke) are more like reflect ive activities and formalization estimating more and valorizing employees[25]. The 5S method is also a philosophy of essential participative management to manage and organize jobs (technical and administrative) with the aim of optimizing the productivity, establishing and perpetuating a state of mind which will contribute to the continuous improvement and to competitiveness. It requires however a support and a strong implication of the hierarchy to insure the follow-up and tasks control.

\section{Validation Approach in Algerian Firm}

\subsection{Study Context}

As an important producer of gas (fourth in the world), Algeria is an excellent supplier for the countries of the north bank of the Mediterranean Sea. The natural gas being a source of energy less polluting than the oil or the coal arouses an increasing interest more and more looked for both for reasons of environment and efficiency. In front of the international important demand of Algerian gas, several infrastructures of gas are born and so come to strengthen the already existing units to strengthen the productive capacity. The supply of the liquefied natural gas requires heavy, complex and expensive industrial plants but is expanding of opportunities as well for the producing countries as the consumer countries in terms of transport and flexibility. It will lead important socioeconomic effects in the countries of transit while contributing to the environmental protection.

The Liquefied natural gas has a very promising future and Algeria already positions in pole position in this juicy market. The process of liquefaction allows condensing the natural gas in GNL by reducing its volume of a factor of about 600 for the same calorific value, what facilitates its transport by sea route. Besides, it consumes an important quantity of energy: the factory of liquefaction uses about $12 \%$ of the gas which is delivered to him for his own functioning, in particular to feed its hot air pumps. The production of the vapour plays an important role as source of energy for the functioning of diverse equipment (generative turbo: electricity production, turbo compressors: compression of gas KT (110/120/121/130), heaters: for the exchange of heat, turbo pumps: for the functioning of pumps, cooling, condensations). This vapour is produced[26] by a set of eighteen ( 18 ) boilers for six ( 6 ) capable trains each to produce $136 \mathrm{~T} / \mathrm{H}$ of vapour in 62 bars $440{ }^{\circ} \mathrm{C}$. the boiler which is characterized by an upper interconnected lower ball (balloon) and a ball (balloon) by tubes taking on the combustion chamber. The boiler is fed with water by pumps thanks to a saver which warms the water of supply in $109^{\circ} \mathrm{C}$ and 65bars. By convection, the water circulates through both superimposed balloons, upper balloon or balloon vapour separate the water of the vapour which formed in tubes. The vapour is taken back at the top of the upper balloon and overheated in $445^{\circ} \mathrm{C}$. At the release, the vapour gets through a desuperheater which returns the temperature of vapour to $440^{\circ} \mathrm{C}$. Every boiler is equipped with two ( 2 ) burners fed on one hand with gas (or it gasoline) by the combustible gas network, on the other hand in air the supply of which is assured by a turbo ventilator. Each of the parameters of the boiler must be checked to assure the smooth running and the maximal efficiency on the boiler. This control is made by instruments of transmission, indication and regulation, strengthened for more safety by switches to give the alarm is to provoke releases. The process of production of the component "boiler" is characterized by:

- Elements incomers (raw material): gas, Ignition (Combustion air), Water.

- Elements of exit (release): the boiler produces 136t / hour of vapor in 62 bars and $440^{\circ} \mathrm{C}$.

- The resources: combustion air, Gas.

- The piloting: the control and the regulation of all the boilers of the complex are assured by the digital system of control command (SNCC or DCS).

\subsection{Identification of Dysfunctions}

The validation of the method 5S was tried on the "boiler", a constituent of a gas Algerian company, which frequently broke down. To correct these distortions, it is necessary to make so that the breakdowns do not occur any more. It is thus necessary to analyze the situation and to discover the origin of the incidents which increase the maintenance cost. Among the current techniques, the diagram of Ishikawa allows to look for the causes of quality problems. The efficiency of this diagram bases on two points: it helps to simp lify a complex problem and it facilitates the group work by directing avenues of research while avoiding neglecting certain important factors. The identified problem is the frequent breakdowns of the boiler. We listed the potential causes in classes by using the diagram of Ishikawa[27] following the rule of 5M (Material, Workforce, Machines, Methods, Environ ment).

The diagram (Figure 1) shows a vision of the defects generating frequent breakdowns.

For example in "the family Workforce" the cause of a breakdown of the boiler can be faults of communication between the performer and the employer.

\subsection{Application of the $5 \mathrm{~S}$ Method}

We applied the 5S method to these dysfunctions. Every "S" is applied to every dysfunction found from the diagram of Ishikawa (Table 4). 


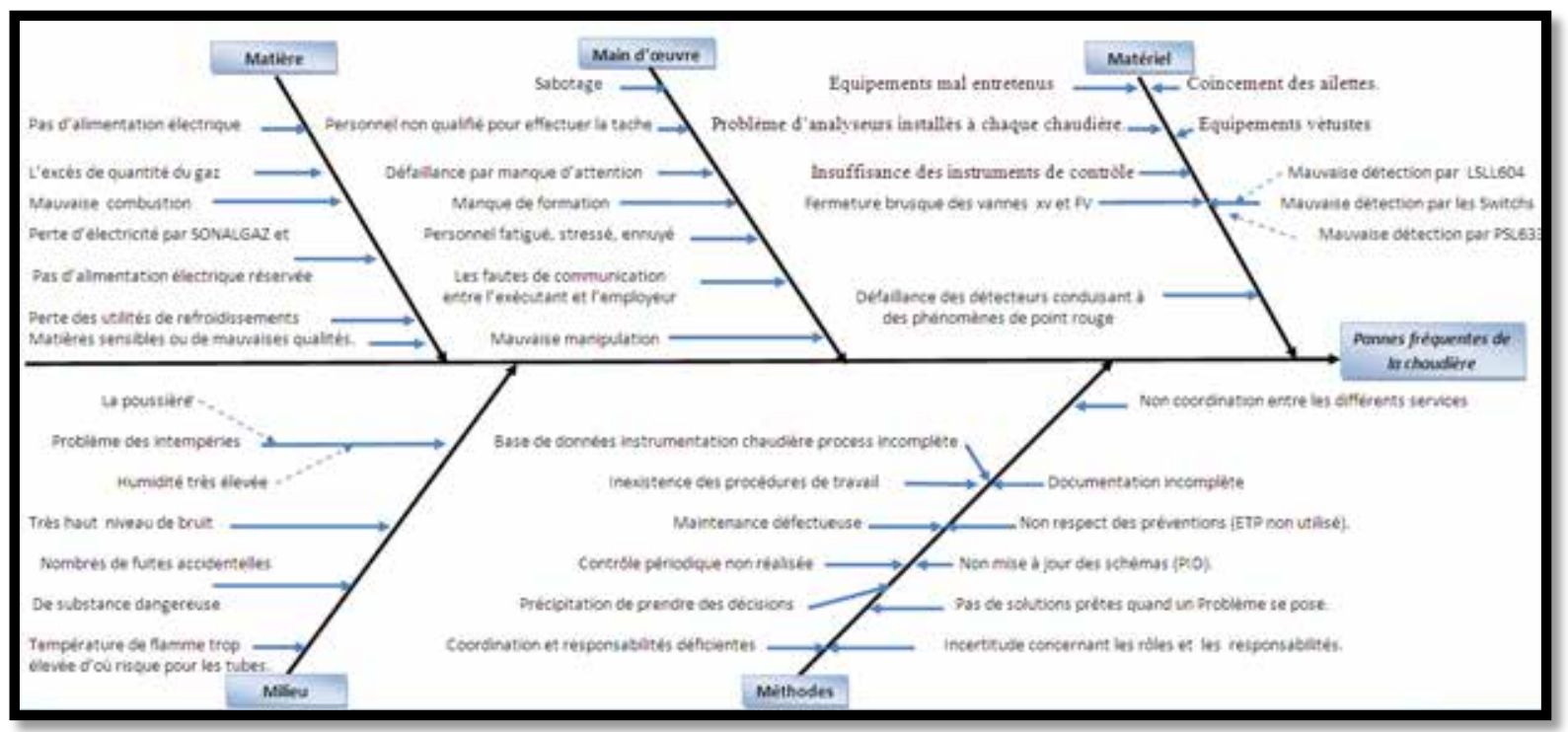

Figure 1. Ishikawa Diagram

Table 4. Application of the $5 \mathrm{~S}$ method

\begin{tabular}{|c|c|c|c|c|c|c|}
\hline \multirow{2}{*}{ Ishikawa axis } & \multirow[t]{2}{*}{ Dysfunctions } & \multicolumn{5}{|c|}{ Method5S } \\
\hline & & 1 & 2 & 3 & 4 & 5 \\
\hline \multirow{7}{*}{ Raw materials } & No power supply & $\mathrm{X}$ & & $\bar{X}$ & & \\
\hline & Loss of the utilities of cooling & & $\mathrm{X}$ & & & \\
\hline & Sensitive mat erials or bad qualities & $\bar{X}$ & $\bar{X}$ & & & \\
\hline & Appearance of gaseous unburned (imperfect mixture Air-Gas) & & $\mathrm{X}$ & $\mathrm{X}$ & & \\
\hline & Bad combustion & & $\mathrm{X}$ & $\mathrm{X}$ & $\mathrm{X}$ & \\
\hline & Excess of quant ity of the gas & $\mathrm{X}$ & & & & \\
\hline & Excess of vapour & $\mathrm{X}$ & & & & \\
\hline \multirow{7}{*}{ Material } & Risk crack of the ceramic filter & & $\mathrm{X}$ & $\mathrm{X}$ & & \\
\hline & Dilapidated equipments and not corresponding parts & $\mathrm{X}$ & & & & \\
\hline & Badly maint ained equipments & $\mathrm{X}$ & & & & \\
\hline & Problem of analyzers installed in every boiler & $\mathrm{X}$ & $\mathrm{X}$ & $\mathrm{X}$ & & $\mathrm{X}$ \\
\hline & Jamming of fins & & $\mathrm{X}$ & $\bar{X}$ & & \\
\hline & Bad placement of the probe at the level of the boiler & & $\mathrm{X}$ & $\mathrm{X}$ & & $\underline{X}$ \\
\hline & Bad exploitation of arrest of the boiler & $\mathrm{X}$ & $\mathrm{X}$ & $\mathrm{X}$ & & $\mathrm{X}$ \\
\hline \multirow{15}{*}{ Environment } & Problem of the dust & & $\mathrm{X}$ & & & $\mathrm{X}$ \\
\hline & Very high humidity & & $\mathrm{X}$ & & & $\mathrm{X}$ \\
\hline & Very high level of noise & & $\mathrm{X}$ & & & $\mathrm{X}$ \\
\hline & Problem of the bad weather (rain) & & $\mathrm{X}$ & & & $\mathrm{X}$ \\
\hline & Numbers of accidental leaks of dangerous subst ance & & $\mathrm{X}$ & & & $\mathrm{X}$ \\
\hline & Temperat ure of too much brought up flame where from risk for tubes & & $\mathrm{X}$ & & & $\mathrm{X}$ \\
\hline & Database instrumentation boiler process incomplete & & $\mathrm{X}$ & & $\mathrm{X}$ & $\mathrm{X}$ \\
\hline & Non-existence of the working procedures & $\underline{X}$ & $\mathrm{X}$ & $\mathrm{X}$ & $\underline{X}$ & $\underline{X}$ \\
\hline & Incomplete documentation & $\mathrm{X}$ & & & $\mathrm{X}$ & $\mathrm{X}$ \\
\hline & Defect of protection & $\mathrm{X}$ & & & $\mathrm{X}$ & $\mathrm{X}$ \\
\hline & Defective and unimplemented maintenance & & $\mathrm{X}$ & & $\mathrm{X}$ & $\mathrm{X}$ \\
\hline & Unimplemented periodic control & & $\mathrm{X}$ & & $\mathrm{X}$ & $\mathrm{X}$ \\
\hline & Haste in the decision-making & & $\mathrm{X}$ & $\mathrm{X}$ & $\mathrm{X}$ & $\mathrm{X}$ \\
\hline & Uncertainty concerning the roles and the responsibilities & & $\mathrm{X}$ & $\mathrm{X}$ & $\mathrm{X}$ & $\mathrm{X}$ \\
\hline & Coordination and deficient responsibilities & & $\mathrm{X}$ & $\bar{X}$ & $\mathrm{X}$ & $\mathrm{X}$ \\
\hline \multirow{9}{*}{ Workforce } & Bad manipulation & $\mathrm{X}$ & $\mathrm{X}$ & & $\mathrm{X}$ & $\mathrm{X}$ \\
\hline & Miss training & & & & $\mathrm{X}$ & $\mathrm{X}$ \\
\hline & Failure due to the lack of attention & & & & $\mathrm{X}$ & $\mathrm{X}$ \\
\hline & Sabotage & & $\mathrm{X}$ & & $\mathrm{X}$ & $\mathrm{X}$ \\
\hline & Load of too much brought up work & $\mathrm{X}$ & & & $\mathrm{X}$ & $\mathrm{X}$ \\
\hline & Tired, lack of motivation, put under stress, annoyed staff & & & & $\mathrm{X}$ & $\mathrm{X}$ \\
\hline & Individual problem of health & & & & $\mathrm{X}$ & $\mathrm{X}$ \\
\hline & Staff not qualified to make the task & & & & $\mathrm{X}$ & $\mathrm{X}$ \\
\hline & Miss communication bet ween the performer and the employer & & & & $\mathrm{X}$ & $\mathrm{X}$ \\
\hline
\end{tabular}




\subsection{Corrective Actions}

The application of 5S is going to allow committing proposals of future corrective actions to be led. The objective is to eliminate the wasting and to improve the performance of the company.

- Type 1 : Seiri

This stage (Table 5) has for objective to make the difference between the indispensable and the useless and to get rid of all which blocks the job.

Table 5. Proposal corrections for 'Seiri'type

\begin{tabular}{|c|c|c|}
\hline Ishikawa axis & Dysfunctions & Profits \\
\hline Raw material & $\begin{array}{c}\text { No power supply } \\
\text { Maintenance } \\
\text { Set un information } \\
\text { system }\end{array}$ \\
\hline Material & $\begin{array}{c}\text { Sensitive mat erials or bad qualities } \\
\text { Excess of quantity of the gas } \\
\text { Excess of vapor }\end{array}$ & $\begin{array}{c}\text { Maintenance to mitigate and assure the } \\
\text { maintenance of equipments }\end{array}$ \\
\hline Methods & $\begin{array}{c}\text { Dilapidated equipments and not corresponding parts } \\
\text { Badly maint ained equipments } \\
\text { Problem of analyzers installed in every boiler } \\
\text { Bad exploitation of arrest of the boiler }\end{array}$ & $\begin{array}{c}\text { Plan board of communication; Set up an } \\
\text { information } \\
\text { system; Procedures }\end{array}$ \\
\hline Workforce & $\begin{array}{c}\text { Incomplete documentation } \\
\text { Defect of protection } \\
\text { Bad manipulation }\end{array}$ & Improve the working conditions \\
\hline
\end{tabular}

- Type 2 : Seiton

This stage (Table 6) has for objective to clean up things quickly and to cover implicitly all the necessary procedures for that purpose.

Table 6. Proposal corrections for 'Seiton'type

\begin{tabular}{|c|c|c|}
\hline Ishikawa axis & Dysfunctions & Profits \\
\hline Raw material & \begin{tabular}{c}
\multicolumn{2}{c}{ Loss of the utilities of cooling } \\
Appearance of gaseous $\quad$ because of an imperfect mixt ure Air-Gas \\
Bad combustion
\end{tabular} & Renew the material \\
\hline Material & $\begin{array}{l}\text { Risk crack of the ceramic filter } \\
\text { Jamming of fins } \\
\text { Bad invest ment(placement) of the probe at the level of the boiler }\end{array}$ & $\begin{array}{l}\text { Maintenance to mitigate and assure the } \\
\text { maint enance of equipments }\end{array}$ \\
\hline Environment & $\begin{array}{c}\text { Problem of the dust } \\
\text { Very high humidity } \\
\text { Very high level of noise } \\
\text { Problem of the bad weather (rain) } \\
\text { Numbers of accidental flights of dangerous substance } \\
\text { Temperat ure of too much brought up flame where from risk for tubes }\end{array}$ & Improve the working conditions \\
\hline Methods & $\begin{array}{c}\text { Database instrument at ion boiler process incomplete } \\
\text { Defective and unimplemented maintenance } \\
\text { Unimplemented periodic control } \\
\text { Haste in the decision-making } \\
\text { Uncertainty concerning the roles and the responsibilities } \\
\text { Coordination and deficient responsibilities. }\end{array}$ & $\begin{array}{l}\text { Plan board of communication; Set up } \\
\text { an information } \\
\text { system }\end{array}$ \\
\hline
\end{tabular}

- Type 3 : Seiso

This stage (Table 7) has for objective to watch the cleanliness of places so that the job and its environment is appropriate.

Table 7. Proposal corrections for 'Seiso'type

\begin{tabular}{|c|c|c|}
\hline Ishikawa axis & Dysfunctions & Profits \\
\hline Raw material & $\begin{array}{c}\text { No power supply } \\
\text { Appearance of gaseous because of an imperfect mixture Air-Gas } \\
\text { Bad combustion }\end{array}$ & $\begin{array}{c}\text { Maintenance to mitigate and assure the } \\
\text { maint enance of equipments } \\
\text { Renewthe material }\end{array}$ \\
\hline Material & $\begin{array}{c}\text { Risk crack of the ceramic filter } \\
\text { Jamming of fins }\end{array}$ & $\begin{array}{c}\text { Maintenance to mitigate and assure the } \\
\text { maint enance of equipments }\end{array}$ \\
Methods & $\begin{array}{c}\text { Bad placement of the probe at the level of the boiler } \\
\text { Problem of analyzers installed in every boiler } \\
\text { Bad exploitation of arrest of the boiler }\end{array}$ & $\begin{array}{c}\text { Set up an information } \\
\text { system }\end{array}$ \\
\hline
\end{tabular}


- Type 4 : Seiketsu

This stage (Table 8) has for objective of to develop habits (apply rules) and a constant effort that everything remains in order.

Table 8. Proposal corrections for 'Seiket su' type

\begin{tabular}{|c|c|c|}
\hline Ishikawa axis & Dysfunctions & Profits \\
\hline Environment & $\begin{array}{c}\text { Problem of the dust } \\
\text { Very high humidity } \\
\text { Very high level of noise } \\
\text { Problem of the bad weather (rain) } \\
\text { Numbers of accidental flights of dangerous substance } \\
\text { Temperat ure of too much brought up flame where from risk for tubes }\end{array}$ & $\begin{array}{l}\text { Renew the equipment } \\
\text { Improve the working } \\
\text { conditions }\end{array}$ \\
\hline Material & $\begin{array}{l}\text { Bad placement of the probe at the level of the boiler } \\
\text { Problem of analyzers installed in every boiler } \\
\text { Bad exploitation of arrest of the boiler }\end{array}$ & Renew the equipment \\
\hline Workforce & $\begin{array}{c}\text { Miss training } \\
\text { Failure due to the lack of att ention } \\
\text { Tired, lack of motivation, put under stress, annoyed staff } \\
\text { Individual problem of health } \\
\text { Staff not qualified to make the task } \\
\text { Miss communication between the performer and the employer } \\
\text { Load of too much brought up work } \\
\text { Sabotage }\end{array}$ & $\begin{array}{l}\text { Improve the working } \\
\text { conditions }\end{array}$ \\
\hline Methods & $\begin{array}{c}\text { Incomplete documentation } \\
\text { Defect of protection } \\
\text { Dat abase instrumentation boiler process incomplete } \\
\text { Defective and unimplemented maintenance } \\
\text { Unimplemented periodic control } \\
\text { Bad manipulation } \\
\text { Haste in the decision-making } \\
\text { Uncertainty concerning the roles and the responsibilities } \\
\text { Coordination and deficient responsibilities. } \\
\text { Non-existence of the working procedures }\end{array}$ & $\begin{array}{l}\text { Set up an information } \\
\text { System; Procedures }\end{array}$ \\
\hline
\end{tabular}

- Type 5 : Shitsuke

This stage (Table 9) has for objective to set up a system allowing to make progress and not to return behind.

Table 9. Proposal corrections for 'Shitsuke' type

\begin{tabular}{|c|c|c|}
\hline Ishikawa axis & $\begin{array}{l}\text { Dysfunctions } \\
\end{array}$ & Profits \\
\hline Workforce & $\begin{array}{c}\text { No power supply } \\
\text { Appearance of gaseous because of an imperfect mixt ure Air-Gas } \\
\text { Bad combustion } \\
\text { Risk crack of the ceramic filter } \\
\text { Jamming of fins } \\
\text { Bad placement of the probe at the level of the boiler } \\
\text { Problem of analyzers installed in every boiler } \\
\text { Bad exploitation of arrest of the boiler }\end{array}$ & $\begin{array}{l}\text { Improve the working } \\
\text { conditions } \\
\text { Clean up the social climate }\end{array}$ \\
\hline Methods & $\begin{array}{c}\text { Bad manipulation } \\
\text { Incomplete documentation } \\
\text { Defect of protection } \\
\text { Uncertainty concerning the roles and the responsibilities } \\
\text { Coordination and deficient responsibilities. } \\
\text { Non-existence of the working procedures } \\
\text { Incomplete documentation } \\
\text { Defect of protection }\end{array}$ & $\begin{array}{l}\text { Set up an information } \\
\text { System } \\
\text { Procedures }\end{array}$ \\
\hline
\end{tabular}

\section{Conclusions}

Lean Manufacturing is designed to optimize all business processes, to eliminate waste and implement a lean organization, agile and efficient. It includes several tools that apply to all environments and facilitate the actions of firm transformation.

Among these tools, the $5 \mathrm{~S}$ method proposed is to improve 
working conditions and safety and results in effects visible very quickly. This approach is based on participative management and plays an essential role in solving problems, the transformation of the workstations environment and accident prevention.

The 5S methodology is very easy to understand, but the hardest is not to understand nor to start a $5 \mathrm{~S}$ approach but to pursue it, hence the importance of visual management so that everyone knows immediately that something in going wrong. To do so, we must develop indicators to monitor the evolution of $5 \mathrm{~S}$ activities (before, during and after).

It is a participatory approach requiring that all persons (employees and responsible) to be present when it is started. It improves productivity, because a pleasant and practical environment saves time and increases quality of life. The concrete success of the methodology developed will depend primarily on the motivation and competence of each agent. Mobilization of each will be crucial to allow optimal organization of resources and activities within the company and will only be directing efforts of all towards achieving the strategic objectives previously validated by the firm manager. In this paper we identified at first the dysfunctions by means of the diagram of Ishika wa and then we applied the tool $5 \mathrm{~S}$ to all the identified causes. We opted for the $5 \mathrm{~S}$ approach because it is a basic tool favoring an environ ment of effective work, creating a dynamics of change, reducing waste and moving the company into the change approach.

This paper is a first step towards improving and will be complemented by other tools at intervals designed to implement other actions. We made a first attempt to apply the $5 \mathrm{~S}$ method in an Algerian firm. The results consist of proposed actions that will allow an improvement of the production process.

\section{ACKNOWLEDGEMENTS}

The authors thank the reviewer for all the remarks and the suggestions.

\section{REFERENCES}

[1] Kotler P., Dubois, B. (2006). Marketing management, $12^{\text {ème }}$ édition, Pearson Education, Paris.

[2] Bellon B. (1991), « La compétitivité », Traité d’Economie Industrielle, Edition Economica, Paris.

[3] Porter M. (1998), " The competitive advantage of nations ", Mac Millan Press, London.

[4] Azouaou, L. et Belouard, A (2010). La politique de mise à niveau des PME algériennes : enlisement ou nouveau départ? $6^{\text {ème }}$ colloque international 21-23 juin 2010 Hammamet (Tunisie).

[5] Garelli, S. (2000), " Competitiveness of Nations : the fondamentals», The World Competitiveness Yearbook.
[6] Mucchielli J.L.,(2002) « La compétitivité, définitions, indicateurs et déterminants ", in Revue Accomex, numéro spécial sur La France est-elle compétitive?, CCIP, mars-avril, N44, p. 9-19.

[7] Lawrence, P., Lorsch, J.(1989), Adapter les structures de l'entreprise,Les Éditions d’Organisation, Paris.

[8] ONUDI (2006), « Programme intégré pour l’amélioration de la compétitivité et l'appui à la restructuration industrielle en Algérie », Vienne.

[9] Madoui, M. (2009). De l'économie administrée à l'économie de marché. Les PME à l'épreuve de la mise à niveau des entrep rises en Algérie, « La vulnérabilité des TPE et des PME dans un environnement mondialisé ", 11es Journées scientifiques du Réseau Entrepreneuriat, 27, 28 et 29 mai 2009, INRPME, Trois-Rivières, Canada.

[10] Real R., Pralus M., Pillet M., Guizzi L. (2007). Une première étape vers le Lean dans les entreprises de sous-traitance mécanique (Retour sur 7 ans de pratique), 5ème Conférence Internationale Conception et Production Intégrées CPI'2007, Cd-rom Art. 041, 16 pages, Rabat (Maroc), 22-24 Octobre 2007.

[11] Womack J., Jones D.(2007), Système Lean : penser l'entreprise au plus juste, Village mondial : Pearson Education, Paris.

[12] Drew J, McCallum B, Roggenhofer, S. (2004), Objectif Lean. Réussir au plus juste : enjeux techniques et culturels, Éditions d'Organisation, Paris.

[13] Sugimori Y., Kusunoki K., Cho F., Uchikawa S. (1977) Toyota Production System and kanban system Materialization of just-in-time and respect-for-human system. International Journal of Production Research; $n^{\circ} 15$, vol 6, pp 553-564.

[14] Kochan A. (1998) The Automotive industry looks for lean production. Assembly Automation; n¹8, vol. 2, pp 132-137.

[15] Baglin G., Capraro M. (1999) L'Entreprise Lean Production ou la PME compétitive par l'action collective, Presses Universitaires de Lyon, Lyon.

[16] Crute V., Ward Y., Brown S., Graves A. (2003) Implementing Lean in aerospace-challenging the assumptions and understanding the challenges. Technovation; $n^{\circ} 23$, pp 917-928.

[17] Abdulmalek F.A., Rajgopal J. (2007) Analyzing the benefits of lean manufacturing and value stream mapping via simulation: A process sector case study. International Journal of Production Economics; n¹07, vol.1, pp.223-236.

[18] Bédry, P. (2009), Les basiques du Lean manufacturing, Eyrolles, Lyon.

[19] Achanga P., Shehab E., Roy R., Nelder G. (2006) Critical success factors for lean implementation within SMEs. Journal of Manufacturing Technology Management; $n^{\circ} 17$, vol.4, pp.460-471.

[20] Ohno T. (1988), Toy ota Production System: Beyond Large Scale Production, Productivity Press.

[21] Liker J. (2004), The Toy ota Way, Mc Graw-Hill, New York.

[22] Imai M. (1986), Kaizen. The Key to Japan's Competitive 
Success, McGraw-Hill, New York.

[23] Trey P. (2003), Le 5S, Socle de l’Efficacité Industrielle : Mode d'Emploi, AFNOR, Paris.

[24] Gillet-Goinard,F. Seno,B (2009), La Boite à outils du responsable qualité, Edition d'Organisation, Paris.

[25] « Pour implanter la méthode "5S", je m'appuie sur les idées de mes salariés » propos recueillis par Marion Deye. In : L'Usine Nouvelle $n^{\circ}$ 2971, 2005.
[26] Fettah, K. Gharrich,N. Azzemou,R. Optimisation des processus de production selon la méthode d'Ishikawa, rapport de licence, Département d’Informatique, USTO (University of Science and Technlogy of Oran), 2010.

[27] Azzemou, R. Noureddine, M. Proposition d'optimisation du processus de production : composant « chaudière " d'une entreprise de gaz. Colloque International « De la coordination des acteurs pour un développement durable de territoires euro-méditerranéens », Bejaia (Algeria), 16-18 mai 2011. 